Southern Methodist University

SMU Scholar

8-2003

\title{
Follow the Leader? Presidential Approval, Presidential Support, and Representatives' Electoral Fortunes
}

\author{
Paul Gronke \\ Reed College \\ Jeffrey Koch \\ SUNY-Geneseo \\ J. Matthew Wilson \\ Southern Methodist University, jmwilson@smu.edu
}

Follow this and additional works at: https://scholar.smu.edu/hum_sci_politicalsci_research

Part of the American Politics Commons

\section{Recommended Citation}

Paul Gronke, Paul; Koch, Jeffrey; Wilson, J. Matthew, "Follow the Leader? Presidential Approval, Presidential Support, and Representatives' Electoral Fortunes" (August 2003). The Journal of Politics, vol. 65, no. 3 , pp. $785-808$.

This document is brought to you for free and open access by the Political Science at SMU Scholar. It has been accepted for inclusion in Political Science Research by an authorized administrator of SMU Scholar. For more information, please visit http://digitalrepository.smu.edu. 


\title{
Follow the Leader? Presidential Approval, Presidential Support, and Representatives' Electoral Fortunes
}

\author{
Paul Gronke \\ Reed College \\ Jeffrey Koch \\ S.U.N.Y.-Geneseo \\ J. Matthew Wilson \\ Southern Methodist University
}

While the link between presidential approval and congressional election outcomes is long established, scholars have generally ignored the role of a member's own voting record in mediating these effects. If voters truly use the congressional ballot to express support or opposition toward the President, then they should not reward or punish all of his fellow partisans equally. Instead, the degree of reward or punishment meted out by voters ought to depend on the member's level of support for the president's legislative initiatives. Using data from the 1993, 1994, and 1996 National Election Studies, we demonstrate two key points: that representatives' actual levels of support for the president are the single greatest predictor of their perceived levels of presidential support, and that perceived levels of presidential support interact powerfully with citizen presidential approval to shape attitudes toward congressional incumbents. These effects dwarf simple partisan heuristics in explaining congressional vote choice, suggesting that citizens are much more discriminating than is typically assumed in using the congressional vote as a referendum on presidential policy.

\section{Introduction}

By all accounts, assessments of presidential performance figure prominently in citizens' evaluations of congressional incumbents. One of the most firmly established facts of electoral politics is that voters with low opinions of the incumbent president vent their anger by voting against his fellow partisans in congressional elections, particularly at the midterm (Abramowitz 1984, 1985; Abramowitz and Segal 1992; Campbell 1993; Cover 1986; Jacobson 1997; Kernell 1977; Marra and Ostrom 1989; Tufte 1975). The policies, programs, and outcomes associated with the current administration serve as important voting cues in these races, and citizens cast the congressional ballot at least in part as an expression of their attitudes toward the president's agenda. Thus, the con- 
gressional vote is, to a significant degree, a referendum on the performance of the sitting president. According to the "restricted in-party culpability thesis" (Fiorina 1983; Hibbing and Alford 1981; Stein 1990; Tufte 1975), if a president is popular and successful, his fellow partisans will reap some electoral benefit; if he is not, they will suffer considerable harm. ${ }^{1}$

In our view, the in-party culpability thesis offers an incomplete account of the relationship between presidential performance evaluations and congressional vote choice. It fails to consider the impact of representatives' actual voting records in mitigating or exacerbating their ties to the incumbent president. ${ }^{2} \mathrm{We}$ contend that when voters distribute punishments or rewards according to their appraisals of the president's job performance, they do not do so on a strictly partisan basis. Instead, they are more discriminating, taking into account a representative's degree of support for the president's policy proposals. Not all Democrats in Congress are loyal supporters of Democratic presidents, nor are all Republicans implacable opponents. Anecdotal evidence suggests that members of Congress are well aware of the importance of presidential popularity for their electoral fortunes and that they cast their roll-call votes accordingly. They may choose to oppose the president at certain strategic points, attempting to minimize the electoral damage that may befall them if they are associated with an unpopular leader; alternatively, they may seek to benefit from a popular president by consistently supporting his agenda. ${ }^{3}$ Indeed, Neustadt (1980) argues that members of Congress are keenly aware of presidential popularity and that it is a key factor in shaping their willingness to support the president's agenda. He provides substantial evidence indicating that members of the opposing party are reluctant to cross a popular president and that many of the president's fellow partisans will jump ship when his popularity is at a low ebb. Unfortunately, little is known about how much this strategic behavior can actually affect public opinion and vote choice.

Here, we address precisely this question. We examine the extent to which citizen perceptions of a representative's level of presidential support are grounded in reality and the degree to which these perceptions influence incumbent evaluation and congressional vote choice. Relatedly, we distinguish between a representative's actual level of presidential support and a respondent's perceptions of that representative's presidential support as influences on incumbent appraisal.

\footnotetext{
${ }^{1}$ Hibbing and Alford (1981) differentiate between the in-party's incumbents and first-time candidates and among incumbents according to their length of service, but not according to the representatives' levels of support for the president.

${ }^{2} \mathrm{~A}$ more nuanced treatment of the subject, taking into account the impact of presidential support, is found in Brady et al. (1996). Their analysis, however, focuses exclusively on aggregate-level data and cannot be used to infer individual-level behavior. Our analysis should provide more insight into the psychological and perceptual dynamics underlying midterm candidate evaluation and vote choice.

${ }^{3}$ Neustadt (1980), for example, argues that members "have to think about the President's standing with the public outside of Washington," and that "public standing is another factor bearing on their willingness to give him what he wants." The same points are echoed by Kernell (1977).
} 
We compare two images of the congressional voter: one who is largely ignorant of the representative's behavior in Washington and who defaults to simple partisan cues in assessing praise or blame, versus one whose evaluation of the incumbent is more discriminating, drawing on impressions of the member's pattern of roll-call votes. In the following section, we elaborate the theoretical and empirical background of our argument. Next, we introduce briefly the data used in our empirical analysis. We then outline our models of how citizens perceive representatives' presidential support, and of the role these perceptions play in candidate evaluation and vote choice. Finally, we subject these models to empirical test and conclude by discussing the implications of our findings for accountability in congressional elections, for policy representation, and for citizens' political discernment.

\section{In-party Culpability and the Rational Electorate}

The restricted in-party culpability thesis maintains that citizens distinguish only between the political parties in assigning blame and credit for national conditions, not between candidates within a party based on how closely they are associated with the activities and programs of the president (Fiorina 1983; Hibbing and Alford 1981). In essence, this view of the electoral process resembles the party-in-government model of electoral behavior: by utilizing partisan and incumbency cues, voters hold accountable elected officials of the party that controls the presidency. ${ }^{4}$ Citizens are granted the sophistication to distinguish between candidates with regard to their partisanship and incumbency status, but little beyond that.

The chief limitation of the in-party culpability thesis is its assumption that citizens see congressional politics solely through the black-and-white lens of member partisanship, overlooking significant variation in levels of presidential support. It underrates the ability of citizens to distinguish among officeholders according to their positions on the president's legislative agenda. A more discriminating electorate would be sensitive not only to simplifying devices like the party of the representative and presidential performance, but also to differences among members of the same party.

This is particularly a concern given the substantial evidence that congressional incumbents behave as if the in-party culpability thesis is an oversimplification of political reality. Previous research at the aggregate level shows that representatives who voted more often with an unpopular president or were otherwise out of step with their constituency were more likely to be defeated than their savvier co-partisans (Brady, Canes-Wrone, and Cogan 2000; Brady et al. 1996). Not surprisingly, representatives (and their electoral opponents) try to affect public per-

\footnotetext{
${ }^{4}$ The restricted in-party culpability thesis holds that presidential performance assessments are of little consequence in open-seat races; only in-party incumbents are substantially tied to the sitting president.
} 
ceptions of their level of support for the president. Regional variations in partisanship and ideology have often led to the formation of groups in Congress who distance themselves from their party and president (e.g., the Boll Weevil Democrats and Gypsy Moth Republicans in the 1970s and 1980s and the Blue Dog Democrats in the 1990s; see also Rohde 1991). "Home style" activity by members is designed at least in part to claim credit for successful administration policies, and to avoid blame for unsuccessful ones (Fenno 1978). Congressional incumbents' well-publicized decisions to have the president appear in districts where he is popular and stay away from ones where he is not suggest that they view perceived presidential proximity or distance as an important element of their reelection strategies. Thus, those with the greatest stake in the electoral process believe that they can affect their electoral prospects by strategically granting or withholding support from the president.

The basic structure of the relationship is presented in Figure 1. We claim that members can alter voter evaluations via a two-step mechanism. Members shift their voting pattern, thus altering the citizen's perceptions of how supportive the member is of the president. Second, citizens use the perceived level of support, along with their own attitudes about the president, to raise (or lower) their summary evaluation of the member's performance.

Thus, individual-level perceptions of member behavior are central to our theory. We have good evidence, based both on anecdotal comments from members and on previous work (Alvarez and Gronke 1996; Wilson and Gronke 2000), that perceptions are based in part on actual member behavior but also in part on partisan cues and projection effects. Thus, besides including actual presidential support in our model, we also ask whether individuals project their own attitudes about the president onto the member (via their own level of presidential approval, interacted with the individual's affective evaluation of the member),

FIGURE 1

Actual Presidential Support, Perceived Presidential Support, and Incumbent Evaluation

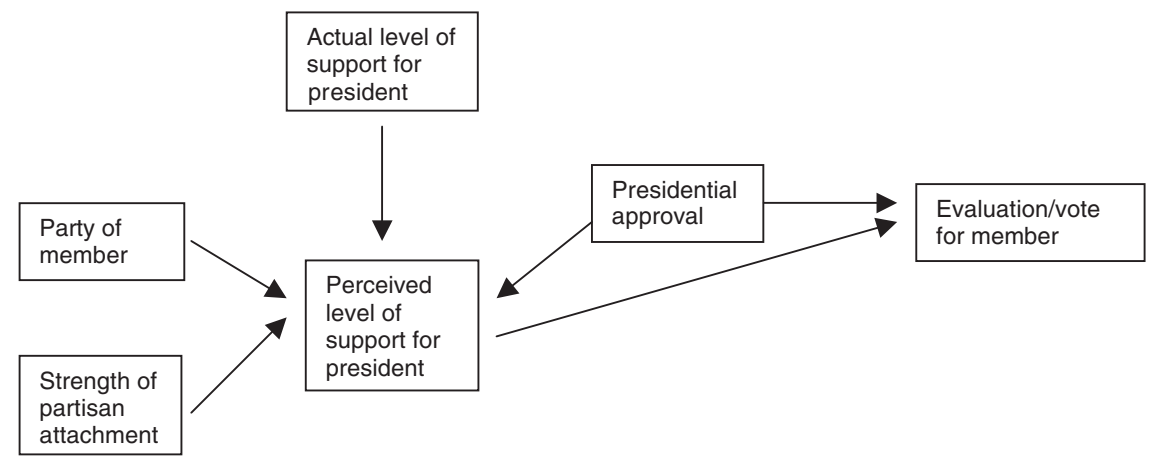


and whether respondents draw on simple partisan cues (Democratic members supported Clinton, Republicans opposed Clinton). In the first part of the article, we estimate a model of perceived presidential support that reflects these relationships.

Once we have determined that perceived presidential support is significantly shaped by actual support and is not purely projection and partisan cueing, we estimate the degree to which a variety of indicators of the respondent's summary evaluation of the member (performance assessments, feeling thermometer scores, and vote choice) are driven by perceived support, presidential approval, and a set of additional independent variables. We also show that while perceived support is a better indicator of an individual's attitudes toward the member than is actual support, actual support interactions retain significant explanatory power in their unmediated form. This section forms the core of our extension to the in-party culpability thesis.

Our contribution in this study is to refine and extend the restricted in-party culpability thesis by taking into account variations in presidential support within a party and, consequently, variations in the effect of presidential approval on incumbent evaluation and vote choice. Essentially, we add to the traditional model of referendum voting the possibility that representatives' actual voting records and their success in fostering a particular political profile in the district may reinforce or mitigate the electoral effects of presidential popularity.

\section{Survey Data on Perceived Presidential Support}

Most of the data for the analyses presented here are drawn from the 1993, 1994, and 1996 National Election Studies (NES). Each includes a measure of respondents' perceptions of their representative's level of presidential support. In each survey, respondents were asked whether their representative generally supported the president's legislative proposals more than half the time, half the time, or less than half the time, or if they did not know. The exact question wording is:

(IF INCUMBENT RUNNING IN R'S DISTRICT): How often has Representative (Name) supported President Clinton's legislative proposals: More than half the time, half the time, less than half the time, or are you not sure?

(IF R ANSWERS MORE/LESS THAN HALF): Would you say that it was almost always/never? ${ }^{5}$

(IF R ANSWERS “NOT SURE"): What would be your best guess: (1993) more than half the time or less than half the time? (1994) more than half the time, half the time, or less than half the time?

\footnotetext{
${ }^{5}$ While this follow-up question should in theory provide insight into important distinctions between members, in practice it sheds little additional light. Virtually everyone (upwards of 90\%) who answered "more than half" followed up with "almost always"; likewise, the great majority of those who answered "less than half" followed up with "almost never." As a result, we have generally ignored this question in our analysis, retaining the "more than half, half, less than half" trichotomy.
} 
Unfortunately, the NES changed these items slightly each year. In 1993 and 1994, respondents who initially failed to offer an estimate were asked to guess how often their member had supported the president. Confusingly, only in 1994 did the follow-up include "about half" as a response choice, thus remaining parallel to the initial query. In 1996, the NES chose not to further probe respondents who initially answered that they were "not sure" how often their member supported President Clinton's legislative proposals. The reason behind this choice, presumably, is the fear that prompting respondents to guess will introduce random variance into the item. Recent research on NES political knowledge measures, however, provides strong evidence for the utility and factual basis of these "guess" responses. Mondak $(2000,2001)$ argues that initial responses of "don't know" often result from a lack of respondent confidence rather than a true lack of knowledge. This assertion is bolstered by previous work showing that "guess" responses are systematically related to characteristics of the representative and respondent in the same way that "know" responses are (Alvarez and Gronke 1996; Wilson and Gronke 2000). Ultimately, the idea of a true, sharp distinction between "knowers" and "guessers" is unsustainable. Instead, there is a continuum ranging from confident respondents with highly detailed, specialized knowledge about member behavior to those who are guessing purely at random without any relevant knowledge. ${ }^{6}$ In any event, because the follow-up query was omitted in 1996, analyses of perceived presidential support employing data from that year will inevitably be hampered by substantially reduced case counts.

For data on representatives' voting records, we use the presidential support scores reported in the Congressional Quarterly Weekly Report. CQ first identifies the set of bills during a particular session on which the president took a public position, excluding those on which the eventual vote was unanimous or near unanimous. The proportion of the time that a member voted with the president's position comprises the support score, ranging potentially from 0 to 100 . In reality, levels of support and opposition are not quite so widely ranged. Actual levels of presidential support in the 103 rd Congress ranged from $21 \%$ to $100 \%{ }^{7}$ The range for members representing congressional districts falling into the 1994 NES has the same maximum and minimum, but a slightly flatter distribution.

The distribution of support within parties is more constrained. Among districts included in the 1994 NES sampling frame, members' levels of presidential support ranged from $60 \%$ to $100 \%$ among Democrats (mean $=78.6$, s.d. $=7.25$ ) and from $21 \%$ to $80 \%$ among Republicans $($ mean $=49.3$, s.d. $=13.72)$. This pattern is a potential concern, as individuals represented by Democratic members seemingly should all respond that their members supported the president "more

\footnotetext{
${ }^{6} \mathrm{We}$ believe that the number of purely random responses is small, even within the "guess" category. The roughly $15 \%$ of the sample who refuse to hazard a guess even when prompted captures most of the respondents who truly have no basis on which to answer the question.

${ }^{7}$ While separate scores are reported in $C Q$ for 1993 and 1994, they track each other quite closely (correlating at .98), so we have averaged each member's scores for the two years.
} 
than half the time." This assumes, of course, that the response categories in the survey item are faithfully used and that respondents are sensitive to actual patterns of legislator behavior. Are both of these conditions satisfied? We turn to this question in the next section, where we evaluate the correlates of perceived presidential support.

\section{Accuracy in Citizen Perceptions of Presidential Support}

For our modification of the in-party culpability thesis to be convincing, we must establish a clear link between representatives' votes for presidential initiatives and their standing among their constituents. First, however, we must demonstrate that citizens are reasonably accurate in their perceptions of how often their members support the president. Long-standing research on policy representation casts doubt on the notion of an electorate that is closely attentive to legislative activity and that evaluates members based on their roll-call behavior (Miller and Stokes 1963; Stokes and Miller 1962). Many citizens have difficulty naming their representative and the electoral opponent and are unable to recall even highprofile roll-call votes (although they seem to be able to infer fairly accuratelysee Alvarez and Gronke 1996; Wilson and Gronke 2000). Indeed, congressional scholars have emphasized the importance of a member's "personal vote," an underlying stratum of support completely unrelated to roll-call voting behavior (Brady et al. 1996; Cain, Ferejohn, and Fiorina 1987; Fenno 1978). Thus, at first glance it seems doubtful that citizens can distinguish representatives who have been loyal supporters of the president from those who have offered only lukewarm support or even outright opposition.

Nevertheless, there are reasons to suspect that voters may be better at estimating their representative's general level of support or opposition to the president's program than they are at identifying individual roll-call votes. No political figure receives the media coverage accorded the president, and presidential initiatives almost always receive a great deal of attention from lawmakers. Even more important, as discussed above, assessments of presidential performance shape vote choice in congressional elections. Since citizens cast their congressional vote partly as a referendum on the incumbent president, they have some incentive to learn how supportive their member has been of the president's legislative proposals, forming an overall impression based in some measure on substantive information. Finally, the one other study that has examined individual survey placements on a general opinion item discovered that a senator's roll-call votes (measured by ADA scores), in combination with the respondent's own ideological predisposition, strongly affected the perceived location of the senator on an ideology scale (Franklin 1991). ${ }^{8}$ Thus, it would seem that actual behavior in

\footnotetext{
${ }^{8}$ Franklin's (1991) study focused on the impact of campaigns in increasing or decreasing the clarity of individual perceptions of a senator's ideology. Like us, however, he wrestled with the difficulty of matching up a survey scale, with attendant measurement error, and a presumably "true" measure of
} 
Washington shapes constituent perceptions of that behavior. Our first set of empirical analyses is devoted to an exploration of this proposition. We seek to ascertain whether citizens lump all members of the president's party together as strong supporters and assume that all members of the opposing party are strong opponents, or whether they are more nuanced in their perceptions of presidential support.

As a first cut at citizen accuracy, we present a bivariate analysis of the relationship between representatives' actual levels of support for the president and the perceptions of those members' levels of presidential support among their constituents. The results of this analysis are reported in Table 1. First we see that, as expected, "guessers" outnumber "knowers" in the sample. In none of the three years did more than $40 \%$ of respondents initially offer an answer to the query about their representative's level of presidential support. In both 1993 and 1994, however, the great majority of the remaining respondents were willing to venture a guess (recall that they were not given this option in 1996). More important, among both "knowers" and "guessers," actual levels of member presidential support track perceived levels of support. Across all items in all years (that is, all initial queries and follow-ups), there is not a single instance in which the actual level of support fails to increase steadily with the perceived level of support. For example, among "knowers" in 1994, members perceived as having supported the president more than half the time actually supported him at a $75 \%$ rate. Members perceived to have been mixed were on average $7 \%$ less supportive, and those thought to have been on balance hostile to the president were another $22 \%$ less supportive (averaging a $46 \%$ rate of support). The pattern is quite similar if we look at other years (1993 or 1996) or if we look at "guessers" instead of "knowers." There appears to be a strong factual basis to these responses.

It is also clearly true, however, that respondents systematically underestimate the level of support that members give to the president's legislative agenda. This is particularly apparent if one looks at the average levels of presidential support among members perceived to have been supportive "about half the time." In all contexts, these figures are in the upper $60 \%$ range, indicating that citizens underestimate the presidential support of these members by $15 \%$ to $19 \%$. This level of misperception on the part of respondents is not really surprising. The actual average level of presidential support in the 103rd Congress (1993-94) was just over 60\%, and even in the Republican-controlled 104th Congress (1995-96) average presidential support continued at a $50 \%$ pace. As scholars of presidential support in the legislature have long noted, representatives from both parties show the president at least some measure of deference (Bond and Fleisher 1990; Edwards 1989). Furthermore, it is important to remember that presidential support scores are calculated as the percentage of votes with the president on

actual roll-call behavior. Also like us, he examined citizen placements on a general item (ideology) in contrast to those studies that examine citizen knowledge of specific roll-call votes (e.g., Alvarez and Gronke 1996; Wilson and Gronke 2000). 
TABLE 1

Perceived and Actual Levels of Presidential Support

\begin{tabular}{|c|c|c|c|c|c|}
\hline & $\begin{array}{c}\text { More than } \\
\text { Half }\end{array}$ & About Half & $\begin{array}{c}\text { Less } \\
\text { than Half }\end{array}$ & Don't Know & F-Test \\
\hline \multicolumn{6}{|c|}{ Respondent Knows Support, 1993} \\
\hline Mean & 74.3 & 68.9 & 44.3 & 61.5 & \multirow[t]{4}{*}{$\mathrm{F}=44.62$} \\
\hline (std dev) & $(16.0)$ & $(18.6)$ & $(18.3)$ & $(21.9)$ & \\
\hline Percent of sample & 12.1 & 6.2 & 5.9 & 75.9 & \\
\hline $\mathrm{N}$ & 74 & 38 & 36 & 466 & \\
\hline \multicolumn{6}{|c|}{ Respondent Guesses Support, 1993} \\
\hline Mean & 69.1 & - & 53.9 & 60.4 & \multirow[t]{4}{*}{$\mathrm{F}=8.42$} \\
\hline (std dev) & $(18.4)$ & - & $(21.4)$ & $(22.7)$ & \\
\hline Percent of Sample & 46.0 & - & 40.6 & 13.5 & \\
\hline $\mathrm{N}$ & 222 & - & 196 & 65 & \\
\hline \multicolumn{6}{|c|}{ Respondent Knows Support, 1994} \\
\hline Mean & 75.3 & 68.3 & 46.2 & 63.5 & \multirow[t]{4}{*}{$\mathrm{F}=53.26$} \\
\hline (std dev) & $(9.0)$ & $(16.7)$ & $(16.8)$ & $(18.6)$ & \\
\hline Percent of Sample & 13.5 & 6.6 & 11.3 & 68.6 & \\
\hline $\mathrm{N}$ & 203 & 99 & 169 & 1028 & \\
\hline \multicolumn{6}{|c|}{ Respondent Guesses Support, 1994} \\
\hline Mean & 74.4 & 65.5 & 52.1 & 63.6 & \multirow[t]{4}{*}{$\mathrm{F}=32.63$} \\
\hline (std dev) & $(11.6)$ & $(17.5)$ & $(19.6)$ & $(18.5)$ & \\
\hline Percent of Sample & 20.3 & 34.0 & 27.4 & 18.3 & \\
\hline $\mathrm{N}$ & 208 & 348 & 281 & 187 & \\
\hline \multicolumn{6}{|c|}{ Respondent Knows Support, 1996} \\
\hline Mean & 77.3 & 67.0 & 49.9 & 63.9 & \multirow[t]{4}{*}{$F=92.62$} \\
\hline (std dev) & (11.4) & $(16.6)$ & $(15.2)$ & $(18.8)$ & \\
\hline Percent of Sample & 16.2 & 7.6 & 16.0 & 60.2 & \\
\hline $\mathrm{N}$ & 181 & 85 & 179 & 672 & \\
\hline
\end{tabular}

Notes: Data from 1993, 1994, and 1996 NES. Voting data coded by authors. Cell entries are the mean presidential support scores for the members representing citizens in the various response categories, the standard deviations of those scores, and the percentage of respondents in each respective response category. The F-test is taken from a one-way ANOVA, assuming unequal variances. All $\mathrm{F}$ statistics are significant at $p<.001$.

issues where he has taken a public position. No president is going to continually expend political capital on losing causes; likewise, presidents support many initiatives that are relatively noncontroversial. Actual presidential support scores will thus be skewed upward, and the degree of this skew is unlikely to be perceived by the general public. It is comparative levels, however, in which we are most interested, and here the data are unmistakable. There is a substantial difference between the answers given by respondents whose representatives were reliable supporters of the president and respondents whose representatives supported him less frequently. It remains to be seen, however, whether these differences survive a more rigorous multivariate analysis. 
Next, we construct a multivariate model with perceptions of support as the dependent variable. Because the dependent variable is trichotomous (less than half, half, more than half), we employ ordered probit estimation. The model is relatively parsimonious, with only five independent variables. Still, we believe it captures the central dynamics of the perceptual process. The first variable, and the one of most theoretical interest to us, is the member's actual level of presidential support in the 103rd Congress (1993-94). As mentioned before, the measure ranges from 21 to 100 in the actual data, with a mean of 63 . To the extent that this variable is significant, we may infer that citizen perceptions of representatives' presidential support are indeed rooted in fact. We also include two measures intended to capture any purely partisan basis to citizen perceptions of presidential support. One is a simple, dichotomous measure of the representative's partisanship, coded 0 for Democratic members and 1 for Republican members. The other represents a more sophisticated interaction of individual partisan intensity and member partisanship. In our view, individuals with stronger partisan attachments are more likely to use partisan cues in processing political information than are individuals with weaker partisanship. Thus, strong partisans are more likely to overestimate Democratic support for Clinton and to underestimate Republican support, all else equal, than are other respondents (Lodge and Hamill 1986). ${ }^{9}$ As an additional control, we include the percentage of the twoparty vote received by Clinton in 1992, under the assumption that respondents could use their district's partisan coloration as a cue in inferring the member's level of presidential support. Finally, we add into the model a variable to test for projection effects. Previous work (Wilson and Gronke 2000) has shown substantial projection in citizen perceptions of member positions on individual roll-call votes, so it is reasonable to assume that such effects may also be present in perceptions of a member's pattern of votes. We expect that respondents who like both their member and the president (or who dislike both) will exaggerate the extent to which the representative has supported Clinton. Conversely, if they like one but not the other, they will underestimate the member's degree of presidential support. These predictions are based in part on insights from balance theory (Heider 1958) and dissonance theory (Festinger 1957), both of which hold that individuals will attempt to increase the cognitive "distance" between differently valenced attitude objects and to decrease the distance between similarly valenced ones. The various possible permutations result in a projection variable coded either 1 or -1 , depending on the hypothesized direction of the effect. ${ }^{10}$

\footnotetext{
${ }^{9}$ This variable is coded 1 to 4 (independent, leaner, weak partisan, strong partisan), and is signed positive for those represented by Democrats and negative for those represented by Republicans (for a total range of -4 to 4 ). Note that independents are not dropped from this analysis. Since they are coded " 1 " on the partisan strength variable, the resultant interaction term has a score of "1" for independents with Democratic representatives and " 1 " for independents with Republican representatives. There is no extra boost for independent identifiers, which is as it should be.

${ }^{10}$ Respondents who like their member and like the president are coded 1 , as are those respondents who dislike both their member and the president. In both cases, the expected projection effect would
} 
TABLE 2

Citizen Perceptions of Member Presidential Support, 1994

\begin{tabular}{|c|c|c|c|c|}
\hline Variable & $\begin{array}{c}\text { Coefficient } \\
\text { (standard error) }\end{array}$ & $\begin{array}{c}\text { Effect at } \\
\text { 1st Threshold }\end{array}$ & $\begin{array}{c}\text { Effect at } \\
\text { 2nd Threshold }\end{array}$ & \\
\hline Actual Support & $.014(.004)^{* * *}$ & -.34 & .29 & \\
\hline Incumbent Party & $-.260(.281)$ & - & - & \\
\hline Incumbent Party* & $.139(.041)^{* * *}$ & -.38 & .35 & \\
\hline \multicolumn{5}{|l|}{ Strength of Party ID } \\
\hline Projection & $.250(.040)^{* * *}$ & -.08 & .16 & \\
\hline District-Wide & $.147(.379)$ & - & - & \\
\hline \multicolumn{5}{|l|}{ Clinton Vote (1992) } \\
\hline 1st Threshold & $.331(.343)$ & & & \\
\hline 2nd Threshold & $1.524(.344)^{* * *}$ & & & \\
\hline \multirow{2}{*}{$\begin{array}{l}N \text { of cases }=989 \\
\chi^{2}=469(4 \mathrm{df})\end{array}$} & $\mathrm{LL}=-851.53$ & $* * * p<.01$ & & \\
\hline & Pseudo $\mathrm{R}^{2}=.216$ & & & \\
\hline Sample Cases & $\begin{array}{l}\text { Range of Actual } \\
\text { Support }\end{array}$ & $\operatorname{Pr}($ Oppose $)$ & $\operatorname{Pr}($ Neither) & $\operatorname{Pr}($ Support) \\
\hline Effect at Mean & - & .28 & .45 & .27 \\
\hline Republican $+/-1 \mathrm{SD}$ & $30 / 54$ & $.65 / .52$ & $.29 / .37$ & $.01 / .11$ \\
\hline Democrat $+/-1 \mathrm{SD}$ & $70 / 82$ & $.17 / .13$ & $.42 / .39$ & $.41 / .48$ \\
\hline Fowler (FL-4), '94-'95 & $62 / 25$ & $.47 / .67$ & $.40 / .27$ & $.13 / .05$ \\
\hline Boehlert (NY-23) '94-'95 & $71 / 47$ & $.42 / .56$ & $.42 / .35$ & $.16 / .06$ \\
\hline Armey (TX-26) '95-'96 & $17 / 37$ & $.71 / .61$ & $.25 / .32$ & $.04 / .07$ \\
\hline
\end{tabular}

Notes: Data from 1994 NES. Estimates were obtained via maximum likelihood ordered probit, estimated in STATA. Effects at each threshold indicate the change in probability that a case will be in category one or category three, relative to the other two categories.

Results from this model are presented in Table 2. To aid in interpretation of the results, we have presented first differences at both thresholds for statistically significant coefficients. ${ }^{11}$ Clearly, partisan cues, projection, and actual support all

be to overestimate the level of support. Those respondents who like their member and dislike the president, or vice versa, are coded -1 . These respondents will tend to underestimate support (for example, if they like their member but dislike the president, they should "reward" that member by increasing the perceived distance between him and the president). This is a classic case for the application of Heider's (1958) balance theory, when individuals confront two attitude objects, toward which they may be positively or negatively disposed, and must assess the connection between those two objects. Our coding of each possible permutation in this variable is informed by Heider's claim that individuals will seek to increase cognitive balance in these triads.

${ }^{11}$ The two columns of first differences represent the change in probability that a respondent will be in the lowest or highest category (respectively) of the trichotomous dependent variable, based on a shift of the independent variable in question from its observed minimum to its observed maximum while holding all other variables constant at their means. Thus, first difference figures for a variable of +10 and -8 would mean that going from the minimum to the maximum on that variable makes an individual $10 \%$ more likely to have responded "less than half" and $8 \%$ less likely to have responded "more than half" when asked how often a member supported the president. 
play a role in citizen perceptions. First, note that the interaction of the respondent's strength of partisanship and the member's party is highly predictive of perceived support. Compared to strong partisans represented by Republicans, strong partisans represented by Democrats are 38\% less likely to believe that their member supported the president less than half the time and are $35 \%$ more likely to believe that their member was supportive more than half the time. These effects are calculated with all else held constant-including the member's actual level of support.

Does this model containing the interaction term perform better than one containing only the unmediated party of the member? Party of member has a large and statistically significant coefficient under this alternative specification; however, the $\log$ likelihood test $\left(\chi^{2}=23.2,1\right.$ d.f. $)$ indicates that adding the strength of partisan leanings significantly improves the fit of the model to the data. ${ }^{12}$ This provides additional evidence that individual predispositions as well as member characteristics and performance matter when citizens evaluate their members of Congress. These citizen appraisals are far from perfect, however. There is systematic bias, in the form of projection effects, creeping into constituent perceptions. Those who like both their representative and the president (or who dislike both) are 16\% more likely to believe that their member supported Clinton more than half the time, ceteris paribus.

Most important, however, a member's actual level of presidential support is a highly significant predictor of citizen perceptions, even after taking into account the biases of partisan heuristics and projection effects and after controlling for potential district cues. Judging by the first differences (-.34 and .29), actual support over its full observed range affects citizen perceptions to roughly the same extent as partisanship, establishing a powerful link between constituent perceptions and actual member behavior. ${ }^{13}$ This can be illustrated by examining

\footnotetext{
${ }^{12}$ The actual specification is as follows. The case count is identical, so this model is nested within the model in Table 2. The log likelihood ratio statistic tests whether the unconstrained model provides a significantly improved fit of the model to the data (roughly analogous to a Chow test). The actual statistic is $-2 *(\operatorname{LL}(0)-\operatorname{LL}(1))$ and is distributed as a chi-square. This model has one constraint (the interaction term is constrained to zero), so the chi-square has a single degree of freedom. The results demonstrate that the model reported in Table 2 fits the data better than the simpler model with the unmediated party of the member.
}

\begin{tabular}{|c|c|c|}
\hline \multicolumn{2}{|c|}{ Alternative Specification: No Interaction } & \multirow{2}{*}{$\begin{array}{l}\text { Model Statistics } \\
\mathrm{N}=989\end{array}$} \\
\hline 1st Threshold & $-.080(.319)$ & \\
\hline 2nd Threshold & $1.104(.319)$ & $\mathrm{LL}=-863.17$ \\
\hline Actual Support & $.014(.004) * *$ & $\begin{array}{l}\chi^{2}=23.2(1 \text { d.f. })(p<.0001) \\
(\text { compared to Table } 2)\end{array}$ \\
\hline Incumbent Party & $-1.05(.156)^{* *}$ & \\
\hline Projection & $.272(.040)^{* *}$ & \\
\hline Clinton Vote & $.152(.155)$ & \\
\hline
\end{tabular}


sample cases. It is not unusual to find members who shift in their levels of presidential support by $20 \%$ or $30 \%$ from year to year. For example, many Republicans became much less supportive of Clinton in 1995 (the first year of the 104th Congress) than they were in 1994, though large intraparty differences remained. Sherwood Boehlert's (NY-23) presidential support score in 1994, for example, was 71, but dropped to 47 in 1995. Similarly, Tillie Fowler's (FL-4)support plummeted from 62 to 25 over the same period. The period from 1995 to 1996 provides a contrast, as many Republicans gave more support to Clinton's agenda as the fervor of the 1994 election faded and the reality of a reelection campaign and a popular out-party president loomed. Republican majority leader Dick Armey (TX-26) was fairly typical, increasing his level of presidential support from 17 to 37 between 1995 and 1996.

Do actual changes in support lead to differences in perceived support? We report the change in the probabilities in the bottom panel of Table 2. We start by comparing Republicans and Democrats who shift one standard deviation above or below the party average. ${ }^{14}$ Ceteris paribus, a movement from the one standard deviation below the average (30) to one standard deviation above (54) increased the probability that a Republican would be perceived as a supporter by $10 \%$. Still, even at one standard deviation above the mean, Republicans are more likely than not $(52 \%)$ to be perceived as opposing the President. More interesting are the specific cases. For example, the probability that a respondent would perceive Sherwood Boehlert (NY-23) as an opponent of Clinton increased from $42 \%$ to $56 \%$ from 1994 to 1995 . A change in voting patterns as large as Tillie Fowler's (FL-4) has an even larger impact, leading to an increase in the probability that she would be seen as opposing Clinton-from $47 \%$ to $67 \%$. Clearly, actual behavior matters, but only insofar as it affects individual perceptions of member positions.

Citizen perceptions of member presidential support are to some degree both inaccurate (generally too low) and biased. Party provides an important cognitive shortcut, and projection effects are clearly discernible. Nonetheless, perceived and actual support correlate to a high degree. The significance of actual support in predicting perceived support is encouraging, indicating that citizen perceptions on this score are substantially grounded in reality. What remains to be seen is how consequential these perceptions are for subsequent political judgment and behavior.

\section{The Effects of Presidential Support on Political Choice}

If members can truly improve their public standing by altering their pattern of presidential support, two conditions are necessary: citizen perceptions of a representative's level of presidential support must be shaped by the representative's actual level of presidential support, and these perceptions must be influential in

\footnotetext{
${ }^{14}$ For all of these comparisons, we have substituted the appropriate values for Incumbent Party $(0$ for Democrats and 1 for Republicans) and for "Incumbent Party*Strength of PID."
} 
candidate evaluation and vote choice. The previous section of the paper has been devoted to establishing the relationship between actual support, partisan cues, projection, and perceived support, as reflected in the left-hand portion of Figure 1. Now we turn to the dependent variables of most interest. We show here that citizens who like the president reward members who support him and punish members who oppose him, while citizens who dislike the president do exactly the opposite.

The central issue for our analysis is whether perceptions of a representative's roll-call support for the president mediate the effects of presidential approval on incumbent evaluation and vote choice. To explore this question, we consider three dependent variables: incumbent feeling thermometer ratings, incumbent job approval, and congressional vote choice. The independent variables are grouped into four categories:

- general attitudes relevant to political evaluations and choice (partisanship, evaluations of Congress, and economic assessments)

- an interaction between respondent presidential approval and perceived or actual member support for the President

- two variables that capture the possibility of uniform, anti-Democratic partisan backlash

- variables that capture potential campaign effects on evaluations and choice

We start with the conventional seven-point partisanship scale, expecting that Democratic respondents will be more favorably disposed toward Democratic members and that Republicans will prefer Republican members. ${ }^{15}$ We add the respondent's attitude toward Congress generally, on the assumption that attitudes toward the institution as a whole might exert at least some influence on the evaluation of individual members, and the respondent's assessment of national economic performance over the past 12 months to control for the possibility of spuriousness, since economic assessments are correlated both with presidential approval and with evaluations of incumbent representatives (Kinder and Kiewiet 1979, 1981; Tufte 1975).

Our concept of critical interest is measured with an interaction term. We have combined the individual presidential approval measure, ranging from -2 (strongly disapprove) to 2 (strongly approve), and multiplied it by the three-fold measure of the representative's perceived presidential support, coded -1 (less than half), 0 (about half), and 1 (more than half). This yields a five-point scale ranging from -2 to 2 . The most negative score $(-2)$ is for those respondents who strongly approve of the president and believe that their member has supported him less than half the time or who strongly disapprove of the president and believe that their member has supported him more than half the time. The most positive score

\footnotetext{
15 "Representative Shares R's Partisanship" is our partisanship variable, recoded to range from -3 to 3 , where 3 represents a strong identifier with the party of the incumbent and -3 represents a strong adherent of the other party.
} 
(2), by contrast, is for exactly the opposite patterns of interaction (respondents with strong negative or positive feelings about the president who perceive their representatives to have patterns of presidential support consistent with their own preferences). ${ }^{16}$ To ensure proper model specification, presidential approval and perception of the representative's level of presidential support are also included as separate variables.

Finally, we include two more sets of variables in order to deal with potential competing hypotheses. We need to control for the possibility of a simple partisan backlash against the in-party. We do this by including two dummy variables in the model. One includes respondents who are represented by Democrats and who approve of the president, while the other includes respondents who are represented by Democrats and who disapprove of the president. The omitted control group is respondents represented by Republicans. If voters were simply punishing all Democratic incumbents, then both of these coefficients should be significant and negative. If voters who disapproved of Clinton were taking out their wrath on all Democrats, the second coefficient should be significant and negative. The inclusion of these variables allows us to assess our relationship of interest uncontaminated by the effects of any partisan backlash at work during this period. ${ }^{17}$ Additionally, since the 1994 and 1996 surveys were taken in the midst of a campaign, we have added measures of campaign spending (incumbent and challenger, logged) and challenger quality, again to control for potential covariation between presidential approval, incumbent approval, and campaign effects. ${ }^{18}$ All of these variables have the potential to influence citizen evaluations of congressional incumbents and congressional vote choice (Canon 1990; Herrnson 2000; Jacobson 1997).

\footnotetext{
${ }^{16}$ Modeling our relationship of interest with a single interaction term assumes a roughly symmetrical impact of positively and negatively valenced judgments when citizens evaluate congressional incumbents. There is at least some evidence in the literature, however, for a negativity bias - in other words, that representatives receive more punishment from voters for behavior at odds with their preferences than they do reward for behavior consistent with those preferences (Cover 1986; Kernell 1977; Key 1966; Lau 1982). We therefore ran all of our models under an alternative specification, with dummy variables representing each possible combination of presidential approval and perceived presidential support, to see if the "discordant" combinations exerted a greater influence on incumbent evaluation and vote choice than the "concordant" ones. While some evidence of a negativity bias does emerge from these models, it is not overwhelming, nor is it consistent across years and evaluative contexts. Thus, we have retained the simpler specification with the single interaction term for presentation here.

${ }^{17}$ These dummy variables also allow us to control for the possibility that any variable that includes "incumbent presidential support" is simply a surrogate for, or certainly highly collinear with, "Democratic members who support Clinton."

${ }^{18}$ Given what is already known about the simultaneous relationship among these variables (Green and Krasno 1988), the coefficients that we will obtain from this model may well be biased. However, multicollinearity among a set of independent variables does not bias other coefficient estimates. Because we are including these mainly as controls, the particular estimates do not greatly concern us.
} 
Evidence of a relationship between perceptions of a representative's degree of presidential support and candidate evaluation is not in itself sufficient to establish that members' actual presidential support influences candidate evaluation. Recall that the analysis of citizens' perceptions of their representatives' presidential support revealed some projection effects. To demonstrate a clear link between a representative's voting record, citizens' perceptions of that record, and assessments of the representative, we need to make sure that actual presidential support itself significantly shapes candidate evaluation. Hence, in addition to models with an interaction between presidential approval and perceptions of the member's presidential support, we present models with an interaction between presidential approval and the member's actual presidential support. While this model does not fully reflect the two-stage process that we argue is at work, it is necessary to examine this evidence to ensure that the results from our main models of interest are not an artifact of projection effects or other cognitive biases. $^{19}$

We report the results from our incumbent feeling thermometer model in Table 3. As expected, shared partisanship makes citizens more favorably disposed toward their representatives. Approval of Congress as a whole has some positive impact in all three years but is statistically significant only in 1996. The campaign variables operate basically as expected and are uniform in direction but mixed in their level of significance. Good, well-funded challengers seem able to drive down the favorability ratings of incumbents, at least marginally. Focusing on our key variables of interest, the interactions of perceived support and actual support with presidential approval are highly significant across all three years. Based on estimates from the model where actual support is interacted with presidential approval, in 1993 citizens who strongly approve of President Clinton would rate their representative about 9 points higher on the feeling thermometer, ceteris paribus, if that member supported the president more than half the time than if he supported the president less than half the time. This difference increases to 10 points in 1994 and 1996. Effects using estimates from the model employing the perceived support interaction are even more substantial. It is important to note that only one of the partisan backlash dummies is significant and in only one year, and then not in a direction indicating a backlash. At least in feeling thermometer ratings, citizens seem to be relying on patterns of presidential support rather than simple party-based cues in evaluating incumbents.

Turning to Table 4, we find a very similar pattern. The dependent variable here is a respondent's answer to the question: "Do you approve or disapprove of the job Representative (Name) is doing as your member of Congress?" Because the

\footnotetext{
${ }^{19}$ To make the analysis of members' actual level of presidential support comparable to those produced from the model with perceptions of members' level of presidential support, the variables were constructed in a similar manner. Members are categorized according to whether they supported the president less than half the time (less than $40 \%$ of the time), about half the time ( $41 \%$ to $60 \%$ of the time), or most of the time (more than $60 \%$ of the time).
} 
TABLE 3

\section{Incumbent Feeling Thermometer Ratings and Presidential Support}

\begin{tabular}{lclllll}
\hline Variable & 1993 & 1994 & 1996 & 1993 & 1994 & 1996 \\
\hline Representative Shares R's & $2.10^{* * *}$ & $3.00^{* * *}$ & $4.39^{* * *}$ & $2.03^{* * *}$ & $3.29 * * *$ & $2.67 * * *$ \\
$\quad$ Partisanship & $(.535)$ & $(.427)$ & $(.658)$ & $(.540)$ & $(.403)$ & $(.361)$ \\
R Approves of Congress & .51 & .68 & $1.87 * * *$ & 1.12 & .84 & $1.62^{* * *}$ \\
$\quad$ Generally & $(.773)$ & $(.554)$ & $(.709)$ & $(.749)$ & $(.540)$ & $(.405)$ \\
National Economic & 1.48 & 1.18 & .80 & 1.65 & $1.31 *$ & .65 \\
$\quad$ Assessments & $(1.10)$ & $(.807)$ & $(1.32)$ & $(1.08)$ & $(.778)$ & $(.711)$ \\
\hline
\end{tabular}

Approval/Support Interaction

\begin{tabular}{lclllll}
\hline Presidential Approval x & $3.19^{* * *}$ & $3.86^{* * *}$ & $6.60^{* * *}$ & & & \\
$\quad$ Rep's Perceived Pres. & $(.709)$ & $(.700)$ & $(1.13)$ & & & \\
$\quad$ Support & & & & & & \\
Presidential Approval & $1.85^{*}$ & $1.61^{* *}$ & $2.96^{* *}$ & & & \\
& $(1.01)$ & $(.807)$ & $(1.21)$ & & & \\
Perceived Presidential & -.31 & -.69 & 3.18 & & & \\
$\quad$ Support & $(1.09)$ & $(1.13)$ & $(1.98)$ & & & \\
Presidential Approval x & & & & $2.25^{*}$ & $2.76^{* * *}$ & $2.56^{* * *}$ \\
$\quad$ Rep's Actual Pres. & & & & $(1.17)$ & $(.966)$ & $(.751)$ \\
$\quad$ Support & & & & & & \\
Presidential Approval & & & & $1.76^{*}$ & .03 & 1.06 \\
& & & & $(1.06)$ & $(.747)$ & $(.691)$ \\
Actual Support & & & & $(2.87$ & -1.05 & 1.92 \\
& & & & $(1.79)$ & $(1.47)$ \\
\hline
\end{tabular}

Partisan Backlash (Anti-Democratic)

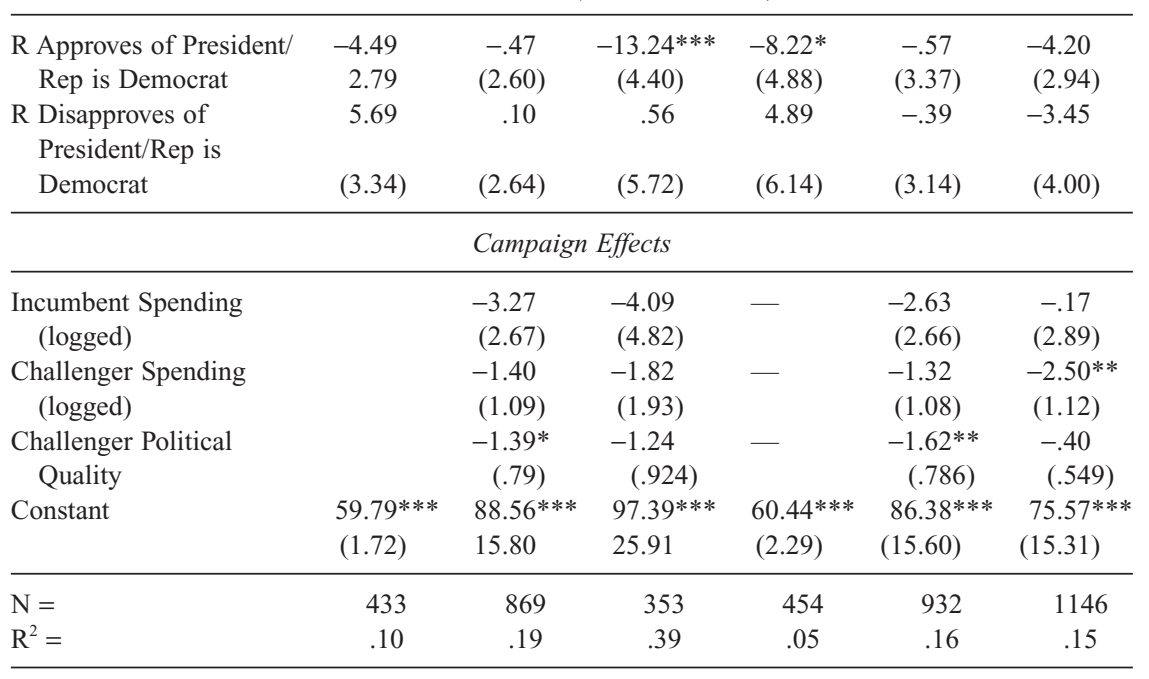

Notes: Data from 1993, 1994, and 1996 NES. 1996 model for perception of incumbent presidential support includes only "knowers" due to question format; see text for more details. Standard errors in parentheses.

$* * *=p<.01, * *=p<.05, *=p<.10$, one-tailed test. 
TABLE 4

Incumbent Job Approval and Presidential Support

\begin{tabular}{lllllll}
\hline Variable & 1993 & 1994 & 1996 & 1993 & 1994 & 1996 \\
\hline Representative Shares R's & $.14 * * *$ & $.21^{* * *}$ & $.25^{* * *}$ & $.13^{* * *}$ & $.23^{* * *}$ & $.18^{* * *}$ \\
$\quad$ Partisanship & $(.045)$ & $(.033)$ & $(.057)$ & $(.044)$ & $(.031)$ & $(.031)$ \\
R Approves of Congress & $.18^{* * *}$ & $.14^{* * *}$ & $.16^{* * *}$ & $.24 * * *$ & $.13^{* * *}$ & $.14 * * *$ \\
$\quad$ Generally & $(.068)$ & $(.045)$ & $(.066)$ & $(.064)$ & .043 & $(.037)$ \\
National Economic & .10 & -.02 & .05 & .09 & -.003 & .02 \\
$\quad$ Assessments & $(.094)$ & $(.061)$ & $(.121)$ & $(.088)$ & $(.057)$ & $(.067)$ \\
\hline
\end{tabular}

Approval/Support Interaction

\begin{tabular}{|c|c|c|c|c|c|c|}
\hline $\begin{array}{l}\text { Presidential Approval x } \\
\text { Rep's Perceived Pres. } \\
\text { Support }\end{array}$ & $\begin{array}{l}.32 * * * \\
(.059)\end{array}$ & $\begin{array}{l}.32 * * * \\
(.055)\end{array}$ & $\begin{array}{l}.53^{* * *} \\
(.109)\end{array}$ & & & \\
\hline Presidential Approval & $\begin{array}{l}.04 \\
(.088)\end{array}$ & $\begin{array}{l}.14 * * \\
(.066)\end{array}$ & $\begin{array}{l}.20^{*} \\
.121\end{array}$ & & & \\
\hline $\begin{array}{l}\text { Perceived Presidential } \\
\text { Support }\end{array}$ & $\begin{array}{l}.11 \\
(.089)\end{array}$ & $\begin{array}{l}.19 \\
.092\end{array}$ & $\begin{array}{l}.14 \\
.180\end{array}$ & & & \\
\hline $\begin{array}{l}\text { Presidential Approval x } \\
\text { Rep's Actual Pres. } \\
\text { Support }\end{array}$ & & & & $\begin{array}{l}.10 \\
(.101)\end{array}$ & $\begin{array}{l}.14^{*} \\
(.078)\end{array}$ & $\begin{array}{l}.23 * * * \\
(.078)\end{array}$ \\
\hline Presidential Approval & & & & $\begin{array}{l}-.08 \\
(.093)\end{array}$ & $\begin{array}{l}-.001 \\
(.059)\end{array}$ & $\begin{array}{l}-.05 \\
(.067)\end{array}$ \\
\hline $\begin{array}{l}\text { Actual Presidential } \\
\text { Support }\end{array}$ & & & & $\begin{array}{l}.22 \\
(.253)\end{array}$ & $\begin{array}{l}-.09 \\
(.146)\end{array}$ & $\begin{array}{l}-.15 \\
(.152)\end{array}$ \\
\hline \multicolumn{7}{|c|}{ Partisan Backlash (Anti-Democratic) } \\
\hline $\begin{array}{l}\text { R Approves of President/ } \\
\text { Rep. is Democrat }\end{array}$ & $\begin{array}{l}-.39 \\
(.237)\end{array}$ & $\begin{array}{l}-.54 * * * \\
(.208)\end{array}$ & $\begin{array}{r}-.78 * * \\
(.381)\end{array}$ & $\begin{array}{l}-.46 \\
(.456)\end{array}$ & $\begin{array}{l}-.20 \\
(.260)\end{array}$ & $\begin{array}{l}.02 \\
(.258)\end{array}$ \\
\hline $\begin{array}{l}\text { R Disapproves of } \\
\text { President/Rep. is }\end{array}$ & & & -.082 & & & -.23 \\
\hline Democrat & $(.273)$ & $(.198)$ & $(.473)$ & $(.591)$ & $(.252)$ & $(.407)$ \\
\hline \multicolumn{7}{|c|}{ Campaign Effects } \\
\hline $\begin{array}{l}\text { Incumbent Spending } \\
\text { (logged) }\end{array}$ & & $\begin{array}{c}-.03 \\
.187\end{array}$ & $\begin{array}{r}-1.10^{* *} \\
(.462)\end{array}$ & & $\begin{array}{l}-.01 \\
(.183)\end{array}$ & $\begin{array}{c}-.03 \\
(.26)\end{array}$ \\
\hline $\begin{array}{l}\text { Challenger Spending } \\
\text { (logged) }\end{array}$ & & $\begin{array}{r}-.11 \\
.087\end{array}$ & $\begin{array}{l}.08 \\
(.176)\end{array}$ & & $\begin{array}{l}-.08 \\
(.082)\end{array}$ & $\begin{array}{l}-.26^{* * *} \\
(.103)\end{array}$ \\
\hline $\begin{array}{l}\text { Challenger Political } \\
\text { Quality }\end{array}$ & & $\begin{array}{r}-.17 \\
.065\end{array}$ & $\begin{array}{l}.038 \\
(.081)\end{array}$ & & $\begin{array}{l}-.16^{* * *} \\
(.062)\end{array}$ & $\begin{aligned} &-.004 \\
&(.047)\end{aligned}$ \\
\hline Constant & $\begin{array}{l}1.18 \\
(.160)\end{array}$ & $\begin{array}{l}2.61 * * * \\
(1.19)\end{array}$ & $\begin{array}{l}7.18 * * * \\
(2.44)\end{array}$ & $\begin{array}{l}1.27 * * * \\
(.230)\end{array}$ & $\begin{array}{c}2.17^{*} \\
(1.12)\end{array}$ & $\begin{array}{l}2.70^{* *} \\
(1.38)\end{array}$ \\
\hline $\mathrm{N}=$ & 414 & 795 & 364 & 425 & 829 & 950 \\
\hline$\chi^{2}(\mathrm{df})=$ & 70.11 & 202.59 & 149.17 & 43.67 & 168.03 & 189.14 \\
\hline Pseudo $R^{2}=$ & .17 & .25 & .39 & .10 & .20 & .21 \\
\hline
\end{tabular}

Notes: Data are from 1993, 1994, and 1996 NES. 1996 model for perception of incumbent presidential support includes only "knowers" due to question format; see text for more details. Standard errors in parentheses. 
dependent variable is dichotomous, these are probit models. Perceived presidential support conditions representative job approval in all three models, and actual presidential support conditions the effect of presidential approval on congressional incumbent evaluation in two of the three models (with the coefficient for 1993 falling short of statistical significance) ${ }^{20}$ Individuals in 1994 who strongly disapprove of President Clinton are $11 \%$ more likely to approve of a representative's job performance if that representative supported Clinton less than half the time than if the representative was supportive more than half the time. In 1996 an identical change increases incumbent approval by $22 \%$. Other variables in the model function as expected. Shared partisanship is an important predictor, and approval of Congress as a whole exerts a positive effect. Once again, the campaign variables are a mixed bag, with generally modest effects, if any. Finally, unlike the feeling thermometer model, there is some evidence here of a generalized backlash against Democrats among Clinton foes in both 1994 and 1996, but only in the models that include perceptions of the representative's level of presidential support.

In Table 5 we present the results of our models for House vote choice. The dependent variable in this model is the reported House vote: respondents who voted to reelect their incumbent are coded 1; those who voted for any other candidate are coded $0 .{ }^{21} \mathrm{We}$ construct the model in this way to allow for direct comparisons with the feeling thermometer and job approval models.

Once again, the interactive effects of presidential approval and perceived presidential support are strong and significant predictors in both models. Moreover, the actual support interaction is an important predictor of incumbent support in the 1996 model (though it falls short of statistical significance in 1994). To illustrate the effect of presidential support on vote choice, we simulate the effect of a change in a Republican incumbent's presidential support for a voter who approves of Clinton's job performance; other variables are set at their mean. In 1996, a change from being a consistent opponent of Clinton to supporting Clinton half the time would increase the likelihood that this voter will support the incumbent by $21 \%$. The impact of the interaction between presidential approval and actual support is of greater magnitude than any other variable except shared partisanship. This should dispel the notion that congressional elections are generally an indiscriminate repudiation or reward of the in-party's candidates. One must look to perceived and actual levels of presidential support to truly understand the dynamics of congressional vote choice.

\footnotetext{
${ }^{20}$ The reader will note that the number of cases for the models that include actual levels of presidential support is greater than those that include perceived levels of presidential support. The models with actual levels of presidential support were rerun on those respondents who offered a perception of the representative's level of presidential support. Coefficients are always larger than those reported here and, at a minimum, reach statistical significance at the .01 level (1-tailed test).

${ }^{21}$ Respondents in districts where there was no incumbent or where the incumbent ran unopposed are excluded.
} 
TABLE 5

House Vote Choice and Presidential Support

\begin{tabular}{lcccc}
\hline Variable & 1994 & 1996 & 1994 & 1996 \\
\hline Representative Shares R's Partisanship & $.42^{* * *}$ & $.55^{* * *}$ & $.434^{* * *}$ & $.46^{* * *}$ \\
& $(.040)$ & $(.074)$ & $(.038)$ & $(.039)$ \\
R Approves of Congress Generally & $.10^{*}$ & .06 & $.12^{* *}$ & $.09^{* *}$ \\
& $(.056)$ & $(.074)$ & $(.054)$ & $(.043)$ \\
National Economic Assessments & -.07 & .04 & -.07 & .10 \\
& $(.076)$ & $(.142)$ & $(.072)$ & $(.077)$ \\
\hline
\end{tabular}

Approval/Support Interaction

\begin{tabular}{llcll}
\hline R Presidential Approval x & $.22^{* * *}$ & $.31^{* * *}$ & & \\
$\quad$ Rep's Perceived Pres Support & $(.066)$ & $(.116)$ & & \\
Presidential Approval & -.05 & .03 & & \\
& $(.083)$ & $(.140)$ & & \\
Perceived Presidential Support & -.06 & .15 & & \\
& $(.110)$ & $(.193)$ & & $.32^{* * *}$ \\
R Presidential Approval x & & & .08 & $(.094)$ \\
$\quad$ Rep's Actual Pres Support & & $(.102)$ & -.02 \\
Presidential Approval & & $-.16^{* *}$ & $(.081)$ \\
& & & $(.079)$ & -.22 \\
Actual Presidential Support & & -.11 & $(.173)$ \\
& & & $(.190)$ & \\
\hline
\end{tabular}

\begin{tabular}{lcccc}
\hline \multicolumn{5}{c}{ Partisan Backlash (Anti-Democratic) } \\
\hline R Approves of President/Rep is Dem & -.26 & $-1.21^{* * *}$ & -.05 & -.34 \\
& $(.249)$ & $(.443)$ & $(.318)$ & $(.272)$ \\
R Disapproves of President/Rep is Dem & -.363 & $-1.23^{* *}$ & -.52 & -.12 \\
& $(.262)$ & $(.527)$ & $(.338)$ & $(.491)$ \\
\hline & Campaign Effects & & \\
\hline Incumbent Spending (logged) & .26 & -.28 & .22 & -.03 \\
Challenger Spending (logged) & $(.240)$ & $(.523)$ & $(.231)$ & $(.310)$ \\
& $-.21^{* *}$ & -.23 & $-.24 * *$ & $-.22^{*}$ \\
Challenger Political Quality & $(.107)$ & $(.200)$ & $(.104)$ & $(.118)$ \\
& -.10 & -.004 & $-.13 *$ & .06 \\
Constant & $(.076)$ & $(.095)$ & $(.074)$ & $(.055)$ \\
& .77 & 4.05 & 1.30 & 2.07 \\
$\mathrm{~N}=$ & $(1.47)$ & $(2.84)$ & $(1.42)$ & $(1.64)$ \\
$\chi^{2}(\mathrm{df})=$ & 570 & 320 & 602 & 809 \\
Pseudo $\mathrm{R}^{2}=$ & $313.73(11)$ & $228.78(11)$ & $308.83(11)$ & $431.92(11)$ \\
\hline
\end{tabular}

Notes: Data from 1994, 1996 NES. 1996 model for perception of incumbent presidential support includes only "knowers" due to question format; see text for more details. Standard errors in parentheses. 
There is one final caveat to our findings. Thus far, we have discussed the inparty culpability thesis as if it is wholly national in focus. In many respects, however, the relevant choice for voters is local. Imagine the dilemma faced by a Clinton supporter in a district represented by a Democratic member of Congress who is lukewarm toward Clinton: the alternative is almost certainly a Republican candidate who will be even less supportive of the president when in office. Of course, while this argument has intuitive plausibility, we would need some estimate of the ideological positions of all congressional challengers to make a valid assessment. We do not think it is necessary to go this far, however. While the relevant vote choice during an election is between a challenger and an incumbent, the relevant evaluation of job performance is not. Downs' (1957) "expected party differential" implies that voters do indeed consider a challenger's prospective rollcall votes in a future congressional session when they are forced to make a choice between two specific paired alternatives. However, it is much less plausible to assume that these considerations will be factored into a respondent's current feeling thermometer rating or job evaluation of an incumbent, which are not inherently comparative assessments. Thus, since we find very similar patterns of results across all three dependent variables, we believe that our extensions to the in-party culpability thesis are both merited and valid.

\section{Conclusion}

Citizens look to the President for a cue as to how the country is doing, how things are going in Washington, and how well Congress is doing its job. It is perhaps unfortunate that citizens place this much emphasis on presidential performance, but it happens all the same. This article confirms the central role that presidential approval plays in evaluations of congressional incumbents. In that respect, our findings are consistent with previous research. However, we shed light on an important feature of presidential approval that heretofore has been ignored. A rational citizen should not indiscriminately reward or punish members of the president's party based simply on partisan cues. Psychological models such as balance theory or cognitive dissonance would not predict that individuals who disapprove of the president would punish members who they like and who distance themselves from the president. The only way that this behavior would be expected is if individuals misperceive the degree of attachment between their members and the president. Our first section indicates that this sort of misperception does indeed occur to a limited extent, but it also shows that actual presidential support substantially determines variance in perceptions of support.

In this research, we demonstrate the conditional nature of the impact of citizens' presidential performance assessments on congressional vote choice. Citizens are concerned with more than the president's performance-they also take into account their representative's level of support for his agenda. Only when members' perceived records of support or opposition toward the president run counter to their own preferences do voters penalize them to any significant 
degree. In this respect, our findings are an excellent individual-level complement to the aggregate-level findings of Brady and colleagues (Brady, Canes-Wrone, and Cogan 2000; Brady et al. 1996). Moreover, these perceptions of member support for the president appear to be substantially grounded in reality, tracking actual levels of support quite closely. Actual presidential support is a strong, but indirect, predictor of citizens' evaluations of their members of Congress. It is mediated by perceptions, partisanship, and affect toward the member.

This analysis offers a more complex picture of referendum voting as it applies to congressional elections. If the congressional vote is indeed to be seen as a useful referendum on the president's agenda, then it is important to incorporate citizen perceptions of legislators' actions with regard to that agenda. Bloom and Price (1975), Kernell (1977), and Lau (1982), among others, demonstrate the effects of negative assessments of the economy and of presidential performance in congressional elections, but in their analyses the actions of the representative are ignored. A more nuanced picture of congressional referendum voting is supported in our analysis, one that sees citizens as acting with a certain degree of discernment and that sees representatives' strategic positioning vis-à-vis the president as electorally consequential.

The overall view that emerges is of an electorate more complex in its preference formation than is appreciated in previous work. Models of voting in congressional elections must take account of these nuances if they are to capture fully the dynamics of congressional vote choice. Prior work on the influence of presidential performance assessments in congressional elections ignores the activities of representatives, thereby casting them as passive victims or beneficiaries of the president's public standing. There is, to be sure, some validity to this view. Perceptions of a representative's presidential support are strongly influenced by partisan cues and projection effects. However, the member's actual pattern of roll-call votes also plays a role of at least equal importance. Actual support shapes perceptions of support, and these perceptions in turn influence citizen evaluations of congressional incumbents. In both cases, the relationship is quite strong across years and electoral contexts. These results suggest that strategic positioning by incumbents with respect to the president's legislative agenda is indeed electorally prudent. It would seem that representatives who correctly calibrate their support for the president can substantially augment the reward or diminish the punishment that the electorate might otherwise bestow upon them.

Manuscript submitted 26 September 2000

Final manuscript received 19 April 2002

\section{References}

Abramowitz, Alan I. 1984. "National Issues, Strategic Politicians, and Voting Behavior in the 1980 and 1982 Elections." American Journal of Political Science 28(4): 710-21. 
Abramowitz, Alan I. 1985. "Economic Conditions, Presidential Popularity, and Voting Behavior in Midterm Congressional Elections.” Journal of Politics 47(1): 31-42.

Abramowitz, Alan I., and Jeffrey A. Segal. 1992. Senate Elections. Ann Arbor: University of Michigan Press.

Alvarez, R. Michael, and Paul Gronke. 1996. "Constituents and Legsislators: Learning About the Persian Gulf War Resolution.” Legislative Studies Quarterly 21(1): 105-27.

Bloom, Howard S., and H. Douglas Price. 1975. "Voter Response to Short-Run Economic Conditions: The Asymmetric Effect of Prosperity and Recession." American Political Science Review 69(4): 1240-54.

Bond, Jon, and Richard Fleisher. 1990. The President in the Legislative Arena. Chicago: University of Chicago Press.

Brady, David W., Brandice Canes-Wrone, and John F. Cogan. 2000. "Out of Step, Out of Office: Legislative Voting Behavior and House Election Outcomes." In Change and Continuity in House Elections, eds. D. Brady, J. Cogan, and J. Ferejohn. Stanford, CA: Stanford University Press.

Brady, David W., John F. Cogan, Brian J. Gaines, and Douglas Rivers. 1996. "The Perils of Presidential Support: How the Republicans Took the House in the 1994 Midterm Elections." Political Behavior 18(3): 345-67.

Cain, Bruce, John Ferejohn, and Morris Fiorina. 1987. The Personal Vote. Cambridge: Harvard University Press.

Campbell, James E. 1993. The Presidential Pulse of Congressional Elections. Lexington: University Press of Kentucky.

Canon, David T. 1990. Actors, Athletes, and Astronauts: Political Amateurs in the United States Congress. Chicago: University of Chicago Press.

Cover, Albert D. 1986. "Presidential Evaluations and Voting for Congress." American Journal of Political Science 30(4): 786-801.

Downs, Anthony. 1957. An Economic Theory of Democracy. New York: HarperCollins.

Edwards, George E. 1989. At the Margins: Presidential Leadership in Congress. New Haven, CT: Yale University Press.

Fenno, Richard. 1978. Home Style: House Members in Their Districts. Boston: Little, Brown.

Festinger, Leon. 1957. A Theory of Cognitive Dissonance. Stanford, CA: Stanford University Press.

Fiorina, Morris. 1983. "Who Is Held Responsible? Further Evidence on the Hibbing-Alford Thesis." American Journal of Political Science 27(1): 158-64.

Franklin, Charles H. 1991. "Eschewing Obfuscation? Campaigns and the Perception of U.S. Senate Incumbents." American Political Science Review 85(4): 1193-1214.

Green, Donald, and Jonathan Krasno. 1988. "Salvation for the Spendthrift Incumbent." American Journal of Political Science 32(4): 884-907.

Heider, Fritz. 1958. The Psychology of Interpersonal Relations. New York: Wiley.

Herrnson, Paul S. 2000. Congressional Elections: Campaigning at Home and in Washington. Washington, DC: Congressional Quarterly Press.

Hibbing, John R., and John R. Alford. 1981. "The Electoral Impact of Economic Conditions: Who Is Held Responsible?" American Journal of Political Science 25(3): 423-39.

Jacobson, Gary C. 1997. The Politics of Congressional Elections. New York: Longman.

Kernell, Samuel. 1977. "Presidential Popularity and Negative Voting: An Alternative Explanation of the Midterm Congressional Decline of the President's Party." American Political Science Review 71(1): 44-66.

Key, V. O, Jr. 1966. The Responsible Electorate: Rationality in Presidential Voting 1936-1960. Cambridge, MA: Belknap.

Kinder, Donald R., and D. Roderick Kiewiet. 1979. "Economic Discontent and Political Behavior: The Role of Personal Grievances and Collective Economic Judgments in Congressional Voting." American Journal of Political Science 23(3): 495-527.

Kinder, Donald R., and D. Roderick Kiewiet. 1981. "Sociotropic Politics." British Journal of Political Science 11(2): 129-161. 
Lau, Richard R. 1982. "Negativity in Political Perception.” Political Behavior 4(3): 353-78.

Lodge, Milton G., and Ruth Hamill. 1986. "A Partisan Schema for Political Information Processing." American Political Science Review 80(2): 505-20.

Marra, Robin F., and Charles W. Ostrom. 1989. "Explaining Seat Change in the U.S. House of Representatives." American Journal of Political Science 33(3): 541-69.

Miller, Warren E., and Donald F. Stokes. 1963. "Constituency Influence in Congress." American Political Science Review 57(1): 45-56.

Mondak, Jeffrey J. 2000. "Reconsidering the Measurement of Political Knowledge." Political Analysis 8(1): 57-82.

Mondak, Jeffrey J. 2001. "Developing Valid Knowledge Scales." American Journal of Political Science 45(1): 224-38.

Neustadt, Richard. 1980. Presidential Power. New York: Macmillan.

Rohde, David. 1991. Parties and Leaders in the Postreform House. Chicago: University of Chicago Press.

Stein, Robert M. 1990. "Economic Voting for Governor and U.S. Senator: The Electoral Consequences of Federalism." Journal of Politics 52(1): 29-53.

Stokes, Donald F., and Warren E. Miller. 1962. "Party Government and the Salience of Congress." Public Opinion Quarterly 26(4): 531-46.

Tufte, Edward. 1975. "Determinants of the Outcomes of Midterm Congressional Elections." American Political Science Review 69(2): 710-21.

Wilson, J. Matthew, and Paul Gronke. 2000. "Concordance and Projection in Citizen Perceptions of Congressional Roll Call Voting." Legislative Studies Quarterly 25(3): 445-67.

Paul Gronke is associate professor and chair of political science, Reed College, Portland, OR 97202-8199.

Jeffrey Koch is associate professor of political science, State University of New York at Geneseo, Geneseo, NY 14454-1401.

Matthew Wilson is assistant professor of political science, Southern Methodist University, Dallas, TX 75275-0117. 
Copyright of Journal of Politics is the property of Blackwell Publishing Limited and its content may not be copied or emailed to multiple sites or posted to a listserv without the copyright holder's express written permission. However, users may print, download, or email articles for individual use. 